\title{
ACUTE EFFECTS OF THE ADMINISTRATION OF VASOPRESSIN DURING WATER DIURESIS IN THE DOG*
}

\author{
BY JOHN R. JAENIKE \\ (From the Department of Medicine, University of Rochester School of Mcdicine, \\ Rochester, N.Y.)
}

(Submitted for publication July 10, 1962; accepted October 10, 1962)

It is generally accepted that the elaboration of a urine hypertonic to plasma by the mammalian kidney occurs by means of the abstraction of water from the collecting duct lumen into the medullary interstitium (1). The driving force for the movement of water is an osmotic gradient created by the active transport of sodium chloride from the ascending limb of the loop of Henle into the medullary interstitial space, as originally postulated by Wirz (2) and subsequently confirmed by the micropuncture studies of Gottschalk and Mylle (3). By necessity, micropuncture studies are conducted during essentially steady-state conditions. Similarly, urinary concentrating ability is customarily evaluated during the state of hydropenia or at graded levels of osmotic diuresis, but in either case, at maximally effective circulating levels of vasopressin. Few data exist on the precise changes in urinary composition during the achievement of the antidiuretic state. It was postulated that such data might provide further information concerning the role of vasopressin in the renal concentrating process. Consequently, in the present study observations have been made on the urinary changes during the abrupt transition from water diuresis to the antidiuretic state, induced by the administration of maximally effective amounts of exogenous vasopressin. Rather consistent alterations in the concentrations of the various urinary solutes have been observed after the administration of vasopressin. Quantification of the acute response to vasopressin has permitted a study of the effects of certain variables on the concentrating process.

In the interpretation of the present data, the role of urea in the concentrating process in the dog has been considered. Current evidence indicates that in this species urea diffuses from the

* Supported by U. S. Public Health Service grant A-4393. collecting duct lumen into the medullary interstitium along its chemical gradient $(4,5)$. In this fashion urea augments total urinary osmolality above that achieved solely by the concentration of sodium chloride in the medullary interstitial space. If urea attains diffusion equilibrium between tubular lumen and interstitial fluid, then the sodium chloride in the interstitium must be balanced by an equiosmolal concentration of nonpermeating solute within the tubular lumen, as long as osmotic equilibrim exists between these two compartments. This would suggest that the concentration of nonpermeating (nonurea) solute within the urine might provide the most critical index of the two factors considered to be fundamental in the concentrating process, namely, the concentration of sodium chloride achieved and maintained in the medullary insterstitium and the degree of permeability in the distal nephron during the action of vasopressin. Consequently, the concentration of nonurea solute has been used as a measure of total concentrating ability in the interpretation of the present set of experiments.

\section{METHODS AND PROCEDURE}

All experiments were performed on trained, unanesthetized, female mongrel dogs. Most of the studies were done on dogs $\mathrm{T}$ and $\mathrm{A}$, which weighed approximately 18 and $16 \mathrm{~kg}$, respectively. Except for studies during dehydration, dogs were prepared by overnight fasting. but were allowed water freely. All experiments were performed in the morning. After insertion of a Foley catheter, a water load in the amount of 4 per cent of body weight was administered intravenously in the form of 2.5 per cent glucose in water within 20 to 30 minutes. Thereafter, 2.5 per cent glucose in water was given intravenously via a constant infusion pump. The rate of infusion was adjusted to maintain total water balance throughout the entire experiment at the level achieved by the initial water load. No correction was made for insensible loss of water. When a water diuresis and relatively stable rate of urine flow had been attained, samples of 2 to 3 clearance periods were collected. Thirty 


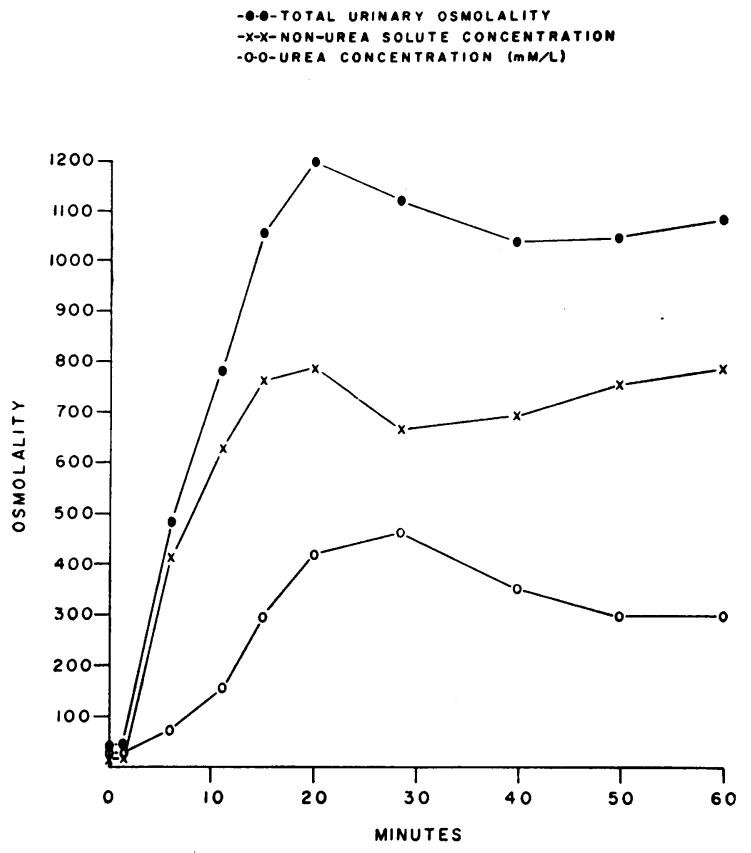

Fig. 1. Changes in total URinary osmolality and THE CONCENTRATIONS OF NONUREA SOLUTE AND UREA AFTER ADMINISTRATION OF VASOPRESSIN DURING WATER DIURESIS. Dog $T$, control experiment of 5/25/61. Vasopressin injected at zero time. The points at zero time represent values from the last control period during water diuresis. The same scheme is used in Figures 2 through 4.

seconds after the completion of the last period during water diuresis, $300 \mathrm{mU}$ of vasopressin (Pitressin, aqueous) was injected through an indwelling needle in a leg vein. Simultaneously, an infusion of vasopressin sufficient to provide $30 \mathrm{mU}$ per $\mathrm{kg}$ of body weight per hour was started and was continued throughout the remainder

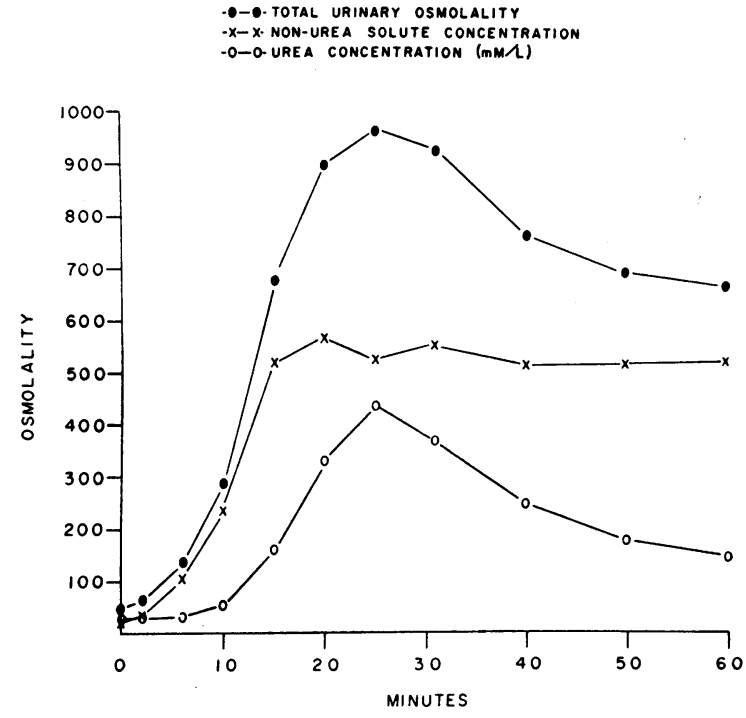

Fig. 2. VASOPRESSin ADMINISTRATION DURING WATER DIUREsis. Dog A, control experiment of $2 / 13 / 61$.

of the experiment. Thirty seconds after the vasopressin priming dose, urine collections were again started. Frequent collections were obtained during the first 25 minutes after the initiation of vasopressin, usually at intervals of 3 to 6 minutes. Thereafter, specimens were collected at 10-minute intervals until 65 minutes; in 3 experiments specimens were obtained up to 130 minutes after the start of vasopressin. Bladder emptying was accomplished by the injection of air followed by manual compression.

In most experiments the clearance of inulin was determined during 2 or 3 periods just before the injection of vasopressin, and for 2 or 3 periods between 35 and 65 minutes after hormone administration. After an initial priming dose, inulin was administered throughout the experiment by means of a Harvard infusion pump. Blood

TABLE I

Data of control experiment of 5/25/61 on dog $T$

\begin{tabular}{|c|c|c|c|c|c|c|c|c|}
\hline Time & $\begin{array}{l}\text { Urine } \\
\text { flow }\end{array}$ & Uos & $\mathrm{U}_{\text {urea }}$ & $\begin{array}{l}\mathrm{U}_{08}- \\
\mathrm{U}_{\text {urea }}\end{array}$ & $\mathrm{UNa}_{\mathrm{a}}$ & Uk & $\begin{array}{l}\text { Inulin } \\
\text { clearance }\end{array}$ & $\begin{array}{l}\mathrm{U} / \mathrm{P} \\
\text { inulin }\end{array}$ \\
\hline minutes & $m l / m i n$ & $m O s m / k g$ & mmole /L & $\mathrm{mOsm} / \mathrm{kg}$ & $m E q / L$ & $m E q / L$ & $m l / m i n$ & \\
\hline \multirow{2}{*}{$\begin{array}{rr}-20- & -10 \\
-10- & 0\end{array}$} & 7.80 & 47 & 31 & 16 & 0.3 & 1.0 & 72.8 & 9.3 \\
\hline & 7.80 & 41 & 28 & 13 & 0.4 & 0.9 & 76.5 & 9.8 \\
\hline \multicolumn{9}{|c|}{ lour by inf } \\
\hline $0-$ & 0.79 & 46 & 28 & $18^{\circ}$ & 2.2 & 1.3 & & 10 \\
\hline $3-$ & 0.47 & 483 & 71 & 412 & 27 & 75 & & 216 \\
\hline $9-13$ & 0.37 & 781 & 155 & 626 & 35 & 140 & & 258 \\
\hline $13-17$ & 0.25 & 1059 & 295 & 764 & 39 & 173 & & 303 \\
\hline $17-23$ & 0.35 & 1201 & 417 & 784 & 88 & 152 & & 268 \\
\hline $23-\quad 35$ & 0.48 & 1123 & 460 & 663 & 150 & 81 & & 180 \\
\hline $35-45$ & 0.57 & 1039 & 349 & 690 & 190 & 69 & 75.5 & 132 \\
\hline $45-\quad 55$ & 0.62 & 1046 & 295 & 751 & 215 & 77 & 76.0 & 123 \\
\hline $55-65$ & 0.51 & 1081 & 298 & 783 & 207 & 98 & 73.3 & 144 \\
\hline
\end{tabular}

Plasma concentrations: $\mathrm{Na}=136 \mathrm{mEq} / \mathrm{L}, \mathrm{K}=3.68 \mathrm{mEq} / \mathrm{L}$, urea $=4.26 \mathrm{mmoles} / \mathrm{L}$, and osmolality $=271 \mathrm{mOsm} / \mathrm{kg}$. 
TABLE II

Data of control experiment of 2/13/61 on $\operatorname{dog} A$

\begin{tabular}{|c|c|c|c|c|c|c|c|}
\hline Time & $\begin{array}{l}\text { Crine } \\
\text { flow }\end{array}$ & Los & Uurea & $\begin{array}{l}\mathbf{U}_{0 s}- \\
\text { Uurea }\end{array}$ & $\mathrm{UN}_{\mathrm{a}}$ & Uk & $\begin{array}{l}\text { Inulin } \\
\text { clearance }\end{array}$ \\
\hline minutes & $m l / m i n$ & $\mathrm{mOsm} / \mathrm{kg}$ & mmoles $/ L$ & $\mathrm{mOsm} / \mathrm{kg}$ & $m E q / L$ & $m E q^{\prime} / L$ & $m l / m i n$ \\
\hline$-30--20$ & 5.0 & 47 & 26 & 21 & 5.8 & 1.1 & 52.5 \\
\hline$-20--10$ & 4.9 & 47 & 26 & 21 & 5.2 & 1.3 & 55.0 \\
\hline$-10-\quad 0$ & 5.1 & 43 & 24 & 19 & 5.5 & 1.3 & 53.5 \\
\hline 0 & $300 \mathrm{mU}$ & ressin i.v & $+30 \mathrm{mU}$ & $\mathrm{kg}$ per ho & infusion & & \\
\hline $0-$ & 0.46 & 57 & 25 & 32 & 6.4 & 1.2 & \\
\hline $4-$ & 0.17 & 132 & 27 & 105 & 24 & 14 & \\
\hline $8-$ & 0.25 & 287 & 51 & 236 & 35 & 38 & \\
\hline $12-$ & 0.17 & 678 & 158 & 520 & 63 & 106 & \\
\hline $18-$ & 0.25 & 896 & 328 & 568 & 112 & 106 & \\
\hline $22-29$ & 0.18 & 964 & 438 & 526 & 171 & 77 & \\
\hline $29-35$ & 0.48 & 924 & 369 & 555 & 219 & 56 & \\
\hline $35-45$ & 0.59 & 763 & 248 & 515 & 226 & 32 & 58.9 \\
\hline $45-\quad 55$ & 0.72 & 694 & 177 & 517 & 226 & 32 & 52.0 \\
\hline $55-65$ & 0.85 & 669 & 147 & 522 & 227 & 37 & 56.5 \\
\hline
\end{tabular}

Plasma concentrations: $\mathrm{Na}=137 \mathrm{mEq} / \mathrm{L}, \mathrm{K}=3.85 \mathrm{mEq} / \mathrm{L}$, urea $=4.30 \mathrm{mmoles} / \mathrm{L}$, and osmolality $=276 \mathrm{mOsm} / \mathrm{kg}$.

for inulin determination was drawn into heparinized syringes from an indwelling venous needle at the midpoint of the clearance periods. Vasopressin solution was prepared from a fresh ampoule at the time of each experiment.

For the evaluation of concentrating ability during hydropenia, dogs were brought to the laboratory after 44 to 48 hours of water deprivation. After catheterization. several clearance periods and one blood sample were obtained. The specimen with the highest concentration of nonurea solute was used for the data presented in Table V.

The response to vasopressin during water diuresis was determined during periods of low protein feeding. Dogs were fed a diet consisting primarily of glucose and oleomargarine, with a small amount of commercial canned dog food added for palatability. The dog food provided approximately $0.2 \mathrm{~g}$ of protein per $\mathrm{kg}$ of body weight. Altogether, 85 to $100 \mathrm{kcal}$ per $\mathrm{kg}$ was given, and in all instances the animals consumed all of the diet offered. The effect of vasopressin during water diuresis was determined after the animals had been receiving the diet for 5 days. In several instances their water was then withdrawn, the diet was continued, and the effect of dehydration on concentrating ability was assessed 2 days later.

Inulin was determined for plasma filtrates and urine with diphenylamine after alkali digestion (6). Urea was estimated by the Conway microdiffusion technique (7), sodium and potassium by internal-standard flame photometry, and osmolality by freezing point depression (8).

\section{RESULTS}

Changes in urinary osmolality. A characteristic response is observed after the administration of a maximally effective amount of vasopressin to the conscious dog during water diuresis. Urinary osmolality rises rapidly, usually attaining maximal values within 20 to 30 minutes. Typically. the concentration of nonurea solute in the urine achieves a maximum at approximately 20 minutes after vasopressin administration. In occasional experiments the maximum is observed somewhat later, at 30 to 50 minutes. These findings are illustrated in Figure 1 and 2, which represent experiments from two dogs. The pattern of response to vasopressin is virtually identical in these two animals, although a marked difference exists in the maximal concentrations of total urinary solute and nonurea solute achieved. The detailed data from these experiments are presented in Tables I and II. Similar patterns of response have been observed in 29 control experiments, including studies performed in two additional dogs. In three experiments on $\operatorname{dog} \mathrm{T}$, observations were extended to 2 hours after vasopressin administration in order to determine whether there occurred a later rise in nonurea solute concentration than would have been observed in the standard 1-hour experiments. A maximal concentration appeared within the first 60 minutes in all studies, although in one experiment it was not observed until 50 minutes.

Further evidence of the rapidity of the effect of vasopressin in the attainment of maximal urinary osmolality has been provided by experiments in which vasopressin was given during combined 
mannitol and water diuresis. By this means, the marked reduction in urinary flow rate immediately after hormone administration was averted, and consequently transit time was reduced and mixing errors minimized. As a result, the nonurea solute concentration attained a virtual maximum more rapidly, at 9 minutes in the experiment shown in Figure 3. Comparable results were observed in another experiment on this animal and in similar studies on two additional dogs.

Alterations in the solute content of the urine. In control experiments, a striking increase in the urinary potassium concentration occurred during the first 20 minutes after vasopressin administration (Tables I and II). During this period it exceeded the urinary sodium concentration. This was a consistent observation, not dependent upon the relative concentration of these ions in the prevasopressin periods. After approximately $20 \mathrm{~min}$ utes, the urinary potassium concentration declined, so that sodium constitued the major urinary cation in the latter half of the postvasopressin period of the experiment. This early increase in the ratio of urinary potassium to sodium concentration was minimal or absent in three experiments on $\operatorname{dogs} \mathrm{T}$ and $\mathrm{A}$ in which a smaller priming close of vasopressin, $30 \mathrm{mU}$, was given (the

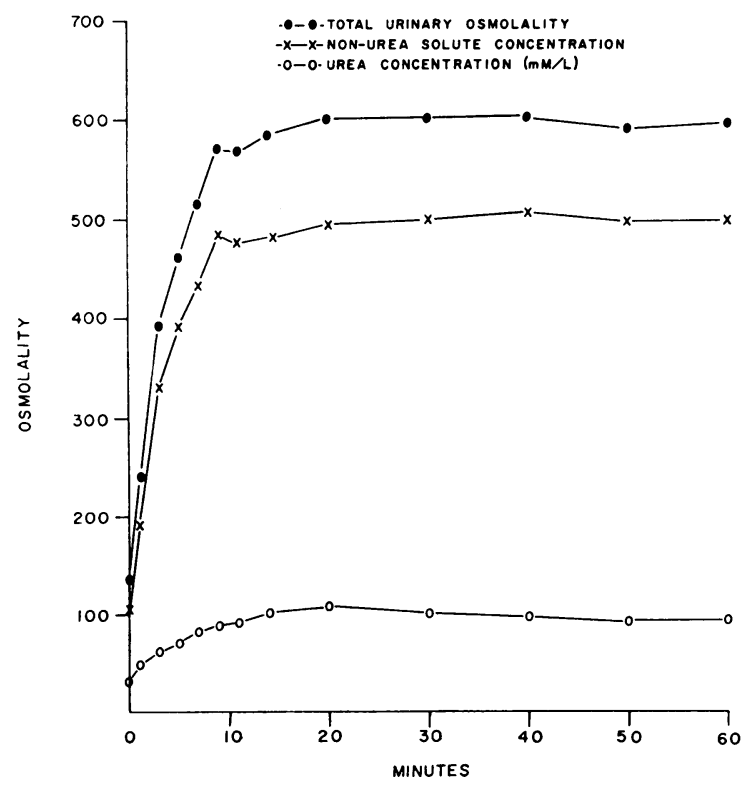

Fig. 3. VASOPRESSIN ADMINISTRATION DURING COMBINED MANNITOL AND WATER diURESIS. Dog T, experiment of $12 / 28 / 61$. standard maintenance dose, $30 \mathrm{mU}$ per $\mathrm{kg}$ per hour, was infused). The latter observation suggests that the early kaliuresis was a result of the large priming dose of vasopressin, $300 \mathrm{mU}$, used in most of the present experiments, and that it may not be an accompaniment of physiological endogenous secretion of this hormone.

In most of the control experiments, the absolute excretion rates of sodium and potassium rose above control levels during the 60 minutes after vasopressin administration. The increase in the excretion rate of sodium was more pronounced than that of potassium (Tables I and II). These findings were also present during the studies referred to above in which smaller priming doses of vasopressin were used, and during two experiments in which lower sustaining doses were given, 3 and $10 \mathrm{mU}$ per $\mathrm{kg}$ per hour, respectively.

No consistent change in glomerular filtration rate (GFR) occurred after vasopressin administration. In 18 control experiments on 3 dogs, in which inulin clearances were determined, GFR rose in 8 , but in only 2 of these was the rise greater than 10 per cent of the control values. Because the change in GFR was within the probable error of the method in most of the experiments, the relationship between filtration rate and sodium excretion could not be evaluated. Alterations in inulin clearance immediately after vasopressin administration could not be assessed because of rapid changes in urinary flow rate, with the attendant dead-space errors.

The initial rise in urinary osmolality after vasopressin administration was primarily attributable to a rapid increase in the concentration of nonurea solute. The disparity in the initial rate of rise in the concentration of nonurea solute and urea is apparent in the control experiments shown in Figures 1 and 2 and in studies done during low protein feeding (Figure 4, Tables III and IV). This disparity was less evident when vasopressin was given during combined mannitol and water diuresis (Figure 3 ), presumably because of the less marked reduction in urinary flow rate under these experimental conditions. These data may be explained by the accumulation of urea in the renal medulla after the action of vasopressin (5), and possibly by loss of urea from the tubular fluid in the distal convolution under the influence of this hormone (9). They may be viewed as the con- 
TABLE III

Data of experiment of 1/24/62 on dog $T$ after 5 days on low protein diet

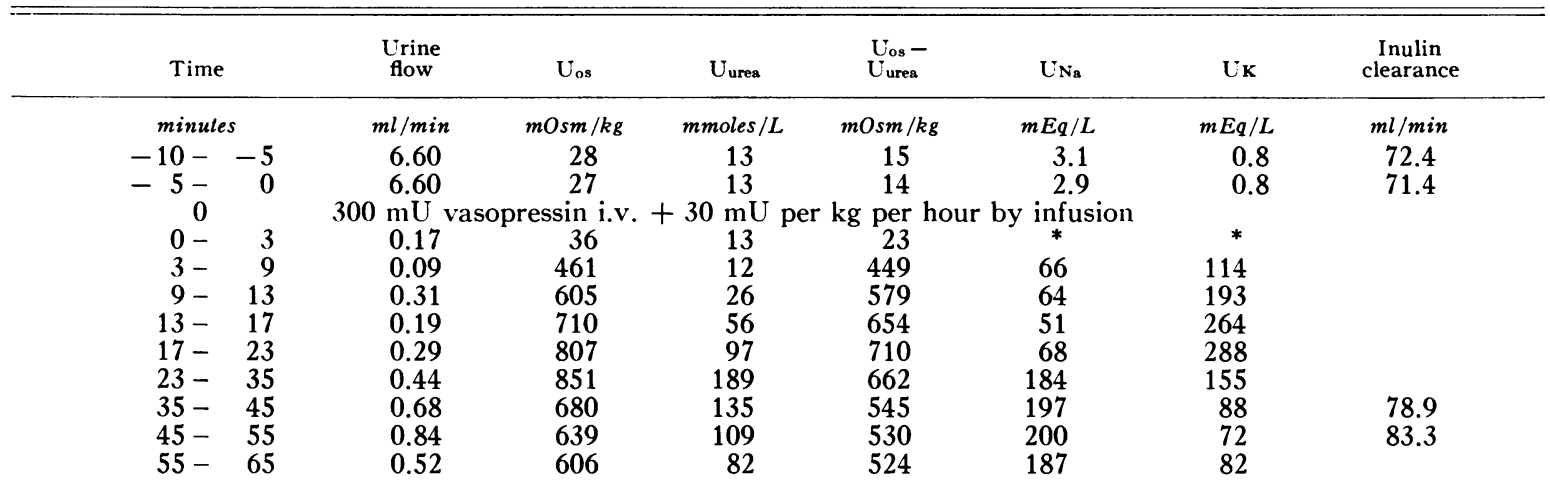

Plasma concentrations: $\mathrm{Na}=143 \mathrm{mEq} / \mathrm{L}, \mathrm{K}=3.87 \mathrm{mEq} / \mathrm{L}$, urea $=1.92 \mathrm{mmoles} / \mathrm{L}$, and osmolality $=278 \mathrm{mOsm} / \mathrm{kg}$.

* Insufficient quantity for analysis.

verse of the "exaltation" of urea excretion occurring during rapidly rising urinary flow rates, as described by Shannon (10). Of interest are certain experiments, particularly those during protein deprivation, in which a marked initial rise in nonurea solute concentration was associated with little or no increase in urinary urea concentration (Tables III and IV). It is not clear whether this observation was most apparent in protein-deprived animals because of the very low urinary flow rates observed after hormone administration, or whether it reflects unique changes in tubular permeability under these experimental con- ditions. Nonetheless, it appears that in certain experiments during the initial period of hormone action, sufficient permeability to urea exists so that the urine becomes concentrated with respect to nonpermeating solutes without significantly concentrating urea within the tubular lumen. The restricted diffusion to urea which exists in the steady state is apparently absent during this transitory period. This suggests the possibility that alterations in the osmolality of the tubular fluid may influence the permeability of the tubular epithelium, a phenomenon demonstrated in the epithelial membrane of the toad

TABLE IV

Data of experiment of 5/9/62 on dog $A$ after 5 days on low protein diet

\begin{tabular}{|c|c|c|c|c|c|c|c|}
\hline Time & $\begin{array}{l}\text { Urine } \\
\text { flow }\end{array}$ & Uos & $\mathrm{U}_{\text {ures }}$ & $\begin{array}{l}\mathrm{U}_{\text {os }}- \\
\mathrm{U}_{\text {ures }}\end{array}$ & $\mathrm{UNa}_{\mathrm{Na}}$ & Uk & $\begin{array}{l}\text { Inulin } \\
\text { clearance }\end{array}$ \\
\hline minutes & $m l / m i n$ & $\mathrm{mOsm} / \mathrm{kg}$ & mmole /L & $\mathrm{mOsm} / \mathrm{kg}$ & $m E \boldsymbol{q} / L$ & $m E q / L$ & $m l / m i n$ \\
\hline$-15--10$ & 4.10 & 22 & 12 & 10 & 3.0 & 0.9 & 55.5 \\
\hline$-10--5$ & 4.60 & 19 & 13 & 6 & 2.9 & 0.9 & 55.0 \\
\hline$-5-0$ & 5.00 & 19 & 12 & 7 & 3.1 & 0.9 & 54.8 \\
\hline 0 & $300 \mathrm{mU} v$ & ressin i.v & $+30 \mathrm{mU}$ & $\mathrm{kg}$ per ho & by infusion & & \\
\hline $0-$ & 0.53 & 23 & 10 & 13 & 4.2 & $*$ & \\
\hline $3-$ & 0.15 & 24 & 15 & 9 & 9 & 2.8 & \\
\hline $7-\quad 12$ & 0.11 & 196 & 17 & 179 & 31 & 16 & \\
\hline $12-19$ & 0.09 & 432 & 23 & 409 & 59 & 41 & \\
\hline $19-24$ & 0.11 & 684 & 77 & 607 & 50 & 79 & \\
\hline $24-\quad 35$ & 0.09 & 843 & 220 & 623 & 60 & 87 & \\
\hline $35-45$ & 0.09 & 889 & 248 & 641 & 115 & 52 & 49.4 \\
\hline $45-\quad 55$ & 0.11 & 964 & 335 & 629 & 139 & 45 & 56.5 \\
\hline $55-65$ & 0.10 & 939 & 379 & 560 & 135 & 39 & 45.2 \\
\hline
\end{tabular}

Plasma concentrations: $\mathrm{Na}=133 \mathrm{mEq} / \mathrm{L}, \mathrm{K}=3.34 \mathrm{mEq} / \mathrm{L}$, urea $=1.40 \mathrm{mmoles} / \mathrm{L}$, and osmolality $=262 \mathrm{mOsm} / \mathrm{kg}$.

* Insufficient quantity for a nalysis. 


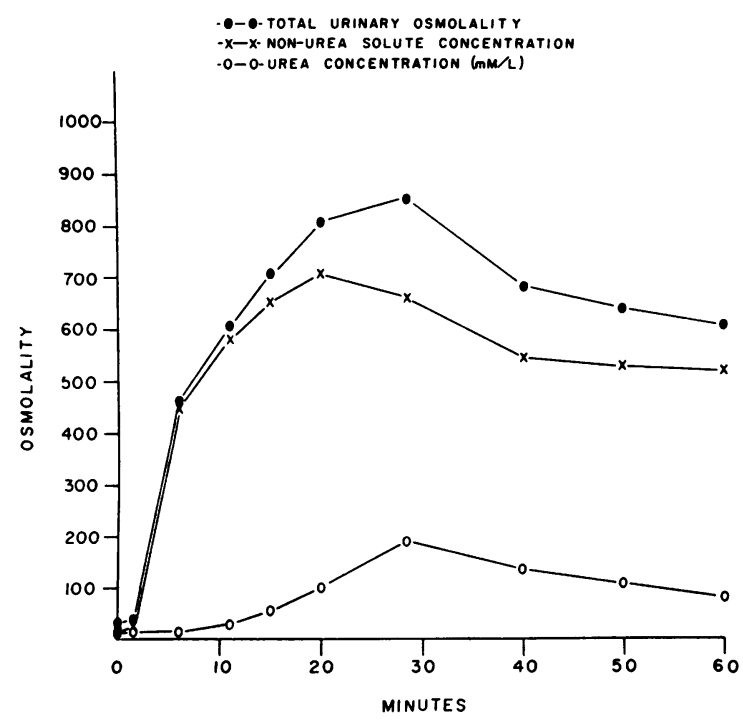

Fig. 4. VASOPRESSin ADMINISTRATION DURING WATER DIUREsis. Dog $T$, experiment of $1 / 24 / 62$. Animal had received a low protein diet during the 5 days before the experiment.

bladder by the studies of Earley, Sidel, and Orloff (11).

Influence of glomerular filtration rate on the acute response to vasopressin. The relationship between urinary concentrating ability and GFR has been examined in $\operatorname{dogs} \mathrm{T}$ and $\mathrm{A}$, in which a large number of experiments have been performed.

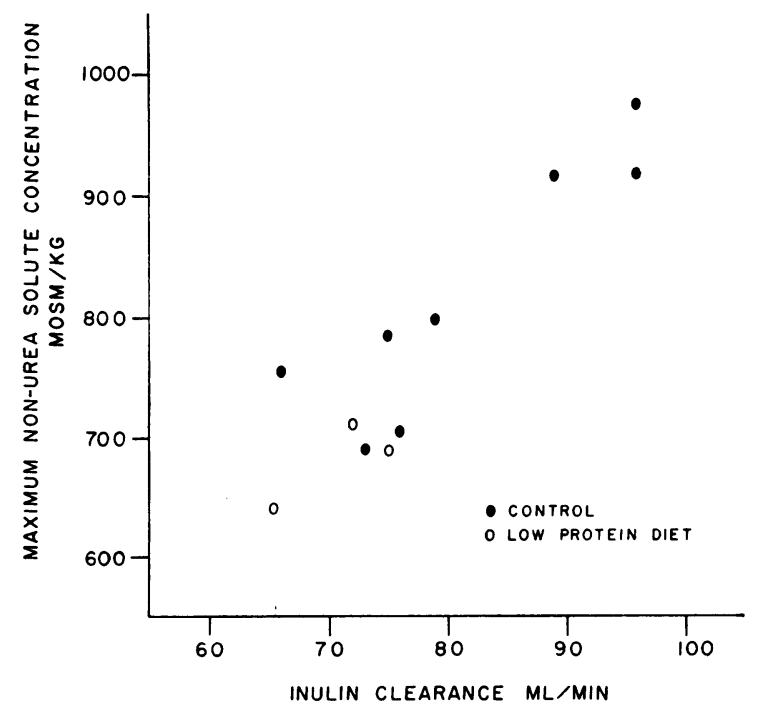

Fig. 5. Relationship of Maximal NONUREa SOlUte CONCENTRATION TO GLOMERULAR FILTRATION RATE. Dog T. Each point represents data from a separate experiment.
These data are presented in Figures 5 and 6. The values for inulin clearance represent the mean of two to three control periods during water diuresis, immediately before the administration of vasopressin. There appeared to be a direct relationship between maximal nonurea solute concentration and GFR in these animals, although the maximal concentrations displayed a moderate amount of scatter in the range of usual filtration rates for the particular dog-70 to $80 \mathrm{ml}$ per minute in $\operatorname{dog} \mathrm{T}$ and 50 to $55 \mathrm{ml}$ per minute in dog A. It should be emphasized that variations in GFR were apparently random and not intentionally introduced into these experiments. It has been postulated that one important factor in this variation was a varying food intake, since animals were maintained on a free standard diet except during the periods of protein deprivation. Evidence for this hypothesis was provided by the observation that these animals did manifest fluctuations in body weight and fasting plasma urea concentration during the period of these experiments. The observed correlation between GFR and concentrating ability agrees with the observations of Goldsmith and his co-workers (12). The present study does not provide evidence on the mechanism of this relationship.

The response to vasopressin during periods of low protein feeding. The effect of a low protein

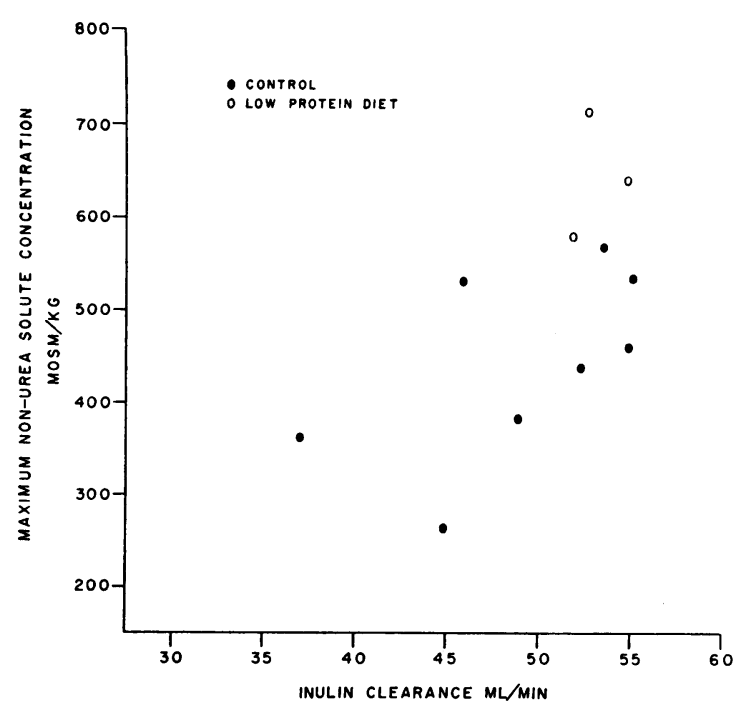

Fig. 6. Relationship of MAXIMAL NONUREa SOLUTE CONCENTRATION to GLOMERUlar FILTRATION Rate. Dog A. Each point represents data from a separate experiment. 
diet on the acute response to vasopressin has been examined in two animals. Three experiments. each representing a separate period of dietary deprivation, have been performed on dogs $T$ and $A$ (Figures 5 and 6 , open circles). In addition, the detailed data from one experiment on $\operatorname{dog} T$ are shown in Figure 4 and Table III, and from one study on Dog A in Table IV. It is apparent from these detailed data that the general pattern of response to vasopressin during water diuresis is not altered by short-term dietary deprivation of protein. The reduction in total urinary osmolality observed is attributable to a decrease in the urinary urea concentration. When maximal nonurea solute concentration is related to GFR in $\operatorname{dog} \mathrm{T}$ (Figure 5), no difference from the control experiments is apparent. In $\operatorname{dog}$ A (Figure 6), higher concentrations than those obtained under control conditions were observed, although in only one experiment is this difference marked. It should be noted that, except for one study in $\operatorname{dog} \mathrm{T}$, the short period of protein deprivation used did not lower GFR below the levels usually observed in these animals.

A comparison of the effects of hydropenia and acute administration of vasopressin. Urinary concentrating ability after 48 hours of water depriva- tion has been compared to that after vasopressin administration during water diuresis in two dogs (Table V). Studies have been performed on regular and low protein diets and have been paired for the sake of comparison. In each instance, the paired studies were conducted within several days of each other, as indicated in Table V. In all instances, a higher total urinary osmolality was observed in the hydropenic state. When the data are examined with respect to nonurea solute. however, a somewhat higher urine to plasma ratio of nonurea solute is present in the hydrated state than during dehydration in control studies. The converse is true in experiments performed during protein deprivation. In most instances, however, these differences are small and of questionable significance. It is apparent from these data that no clearly consistent enhancement of the medullary sodium gradient, as assessed by the determination of the urinary nonurea solute concentration, is present in the dehydrated state over that observed after vasopressin administration to a normally hydrated animal given an acute water load. Since inulin clearance was not measured in the experiments during dehydration, the possible influence of this factor on concentrating ability cannot be evaluated in this set of studies.

TABLE V

Urinary concentrating ability during dehydration and after vasopressin administration during water diuresis. Paired experiments in two dogs under control conditions and during ingestion of a low protein diet

\begin{tabular}{|c|c|c|c|c|c|c|c|c|c|c|}
\hline Dog & $\begin{array}{l}\text { Experiment } \\
\text { conditions }\end{array}$ & & Day* & $\begin{array}{l}\text { Urine } \\
\text { flow }\end{array}$ & $\begin{array}{l}\text { Urine } \\
\text { osmolality }\end{array}$ & $\begin{array}{c}\text { Plasma } \\
\text { osmolality }\end{array}$ & $\begin{array}{l}\text { Urine } \\
\text { urea }\end{array}$ & $\begin{array}{c}\text { Plasma } \\
\text { urea }\end{array}$ & $U_{\text {urea }}$ & $\begin{array}{l}\text { I/P } \\
\text { ratio } \\
\text { non urea } \\
\text { solute }\end{array}$ \\
\hline \multirow{6}{*}{$T$} & & & & $\mathrm{ml} / \mathrm{min}$ & $\mathrm{mOsm} / \mathrm{kg}$ & $\mathrm{mOsm} / \mathrm{kg}$ & mmoles /L & mmoles $/ L$ & $\mathrm{mOsm} / \mathrm{kg}$ & \\
\hline & control & $\begin{array}{l}\mathrm{D}+ \\
\mathrm{H}+\end{array}$ & $\begin{array}{l}0 \\
4\end{array}$ & $\begin{array}{l}0.114 \\
0.634\end{array}$ & $\begin{array}{l}1685 \\
1319\end{array}$ & $\begin{array}{l}307 \\
265\end{array}$ & $\begin{array}{r}1038 \\
479\end{array}$ & $\begin{array}{l}6.0 \\
5.8\end{array}$ & $\begin{array}{l}647 \\
846\end{array}$ & $\begin{array}{l}2.15 \\
3.27\end{array}$ \\
\hline & control & $\underset{\mathrm{H}}{\mathrm{D}}$ & $\begin{array}{r}0 \\
-3\end{array}$ & $\begin{array}{l}0.184 \\
0.364\end{array}$ & $\begin{array}{l}1792 \\
1643\end{array}$ & $\begin{array}{l}310 \\
287\end{array}$ & $\begin{array}{l}919 \\
668\end{array}$ & $\begin{array}{l}7.7 \\
6.6\end{array}$ & $\begin{array}{l}873 \\
975\end{array}$ & $\begin{array}{l}2.89 \\
3.48\end{array}$ \\
\hline & control & $\stackrel{\mathrm{D}}{\mathrm{H}}$ & $\begin{array}{l}\mathbf{0} \\
7\end{array}$ & $\begin{array}{l}0.190 \\
0.375\end{array}$ & $\begin{array}{r}2159 \\
995\end{array}$ & $\begin{array}{l}319 \\
277\end{array}$ & $\begin{array}{r}1480 \\
329\end{array}$ & $\begin{array}{l}8.9 \\
4.0\end{array}$ & $\begin{array}{l}679 \\
666\end{array}$ & $\begin{array}{l}2.19 \\
2.44\end{array}$ \\
\hline & low protein & $\underset{H}{\mathrm{D}}$ & $\begin{array}{r}0 \\
-2\end{array}$ & $\begin{array}{l}0.081 \\
0.287\end{array}$ & $\begin{array}{r}1496 \\
851\end{array}$ & $\begin{array}{l}315 \\
278\end{array}$ & $\begin{array}{r}526 \\
97\end{array}$ & $\begin{array}{l}4.3 \\
1.9\end{array}$ & $\begin{array}{l}870 \\
710\end{array}$ & $\begin{array}{l}2.80 \\
2.57\end{array}$ \\
\hline & low protein & $\stackrel{\mathrm{D}}{\mathrm{H}}$ & $\begin{array}{r}0 \\
-2\end{array}$ & $\begin{array}{l}0.078 \\
0.178\end{array}$ & $\begin{array}{r}1182 \\
713\end{array}$ & $\begin{array}{l}307 \\
272\end{array}$ & $\begin{array}{r}396 \\
73\end{array}$ & $\begin{array}{l}4.4 \\
2.0\end{array}$ & $\begin{array}{l}786 \\
640\end{array}$ & $\begin{array}{l}2.60 \\
2.37\end{array}$ \\
\hline \multirow[t]{4}{*}{ A } & control & $\underset{\mathrm{H}}{\mathrm{D}}$ & $\begin{array}{l}\mathbf{0} \\
\mathbf{3}\end{array}$ & $\begin{array}{l}0.183 \\
0.350\end{array}$ & $\begin{array}{l}1543 \\
1201\end{array}$ & $\begin{array}{l}308 \\
278\end{array}$ & $\begin{array}{l}940 \\
610\end{array}$ & $\begin{array}{l}8.5 \\
7.0\end{array}$ & $\begin{array}{l}603 \\
591\end{array}$ & $\begin{array}{l}2.01 \\
2.18\end{array}$ \\
\hline & control & $\underset{\mathrm{H}}{\mathrm{D}}$ & $\begin{array}{l}\mathbf{0} \\
\mathbf{2}\end{array}$ & $\begin{array}{l}0.200 \\
0.125\end{array}$ & $\begin{array}{r}1278 \\
925\end{array}$ & $\begin{array}{l}319 \\
284\end{array}$ & $\begin{array}{l}749 \\
390\end{array}$ & $\begin{array}{l}7.8 \\
5.5\end{array}$ & $\begin{array}{l}529 \\
535\end{array}$ & $\begin{array}{l}1.70 \\
1.92\end{array}$ \\
\hline & low protein & $\stackrel{\mathrm{D}}{\mathrm{H}}$ & $\begin{array}{r}0 \\
-2\end{array}$ & $\begin{array}{l}0.075 \\
0.156\end{array}$ & $\begin{array}{r}1362 \\
870\end{array}$ & $\begin{array}{l}318 \\
269\end{array}$ & $\begin{array}{l}448 \\
156\end{array}$ & $\begin{array}{l}3.3 \\
1.3\end{array}$ & $\begin{array}{l}914 \\
714\end{array}$ & $\begin{array}{l}2.90 \\
2.66\end{array}$ \\
\hline & low protein & $\stackrel{\mathrm{D}}{\mathrm{H}}$ & $\begin{array}{r}0 \\
-2\end{array}$ & $\begin{array}{l}0.080 \\
0.090\end{array}$ & $\begin{array}{r}1341 \\
889\end{array}$ & $\begin{array}{l}328 \\
262\end{array}$ & $\begin{array}{l}508 \\
248\end{array}$ & $\begin{array}{l}4.1 \\
1.4\end{array}$ & $\begin{array}{l}833 \\
641\end{array}$ & $\begin{array}{l}2.57 \\
2.46\end{array}$ \\
\hline
\end{tabular}

* In each pair of experiments, day 0 is assigned to the study during dehydration (D), and the time difference between this study and that during the hydrated state $(H)$ is indicated by the number of days opposite the designation $\mathrm{H}$. 


\section{DISCUSSION}

The present set of experiments demonstrates that vasopressin administration during water diuresis results in the abrupt achievement of a maximal urinary nonurea solute concentration comparable to the value observed during prolonged vasopressin infusion or dehydration in the same animals. These observations are relevant to certain questions related to the urinary concentrating process, namely, the state of the renal medulla during water diuresis, the role of vasopressin in augmenting the medullary sodium chloride concentration, and the effect of dehydration on renal concentrating ability.

Hyperosmolality of the renal medulla during water diuresis has been demonstrated by indirect means in the $\operatorname{dog}(13)$ and rat (14). By the use of micropuncture. Gottschalk (15) has observed hyperosmolality of vasa recta blood and fluid from the loops of Henle in hamsters with diabetes insipidus. The osmolalities observed were lower than those found in normal, hydropenic animals, however, suggesting the presence of a higher medullary sodium concentration in the latter group. The question of the relative state of the renal medulla during water diuresis and during hydropenia has recently been investigated by Levitin, Goodman, Pigeon, and Epstein (16). By analysis of tissue slices, they have observed that the sodium content of the renal medulla of dogs is lower during water diuresis than after the administration of vasopressin to hydrated animals. Twenty-four hours of dehydration further increases the medullary sodium content above that observed during water diuresis. These data have been interpreted as evidence that vasopressin enhances the sequestration of sodium within the renal medulla, thus increasing the interstitial sodium chloride concentration and the osmotic gradient responsible for urinary concentration.

The acute response to vasopressin in the present studies does not suggest a cumulative effect of this hormone on the medullary sodium gradient. although the data do not exclude the possibility that vasopressin may have increased the medullary sodium concentration, with the achievement of a new, higher level for several minutes after its administration. In addition, measurement of the urinary nonurea solute concentration during hydropenia does not indicate that progressive augmentation of the medullary sodium gradient results from prolonged endogenous secretion of vasopressin induced by water deprivation. These data suggest the possibility that the medullary sodium chloride concentration may be comparable during physiological water diuresis and during the antidiuretic state, whether the latter is produced by the acute administration of vasopressin or by the imposition of hydropenia. The results of the present study thus appear to be at variance with those of Levitin and co-workers (16) and with the micropuncture data of Gottschalk (15), although the latter were not obtained during physiological water diuresis and therefore may not be strictly comparable to the present experiments. Resolution of these apparent discrepancies probably must await more direct measurement of the medullary sodium gradient under varying physiological conditions.

Other investigators have concluded that in both man (17-19) and $\operatorname{dog}(18)$, dehydration augments urinary concentrating ability over that observed after the administration of vasopressin to the normally hydrated or acutely water-loaded subject. This conclusion was based on the finding of a higher total urinary osmolality during dehydration, an observation also made in the present study (Table V). The present data, however. reveal no apparent increase of the nonurea solute concentration of the urine by dehydration. A similar calculation of the data of Epstein. Kleeman, and Hendrikx (17) reveals no increase in nonurea solute concentration during dehydration over that achieved by vasopressin administration during free fluid intake in two normal human subjects on a regular diet. Sufficient data are not reported to enable similar calculations from other published studies. The present findings suggest that the higher total urinary osmolality observed during dehydration is due solely to an increase in the urinary urea concentration. Since urea appears to accumulate passively in the renal medulla of the dog, these findings suggest that the achievement and maintenance of the sodium chloride concentration gradient in the medullary interstitium is not enhanced in hydropenia above that present during normal hydration or acute water-loading. One reservation concerning strict interpretation of these data must. however, be 
made. This relates to the assumption that in the presence of rasopressin, urea closely approaches diffusion equilibrium between collecting duct fluid and the surrounding medullary interstitium. If it does not, then a significant portion of the urinary urea must be osmotically balanced by nonpermeating solute (sodium chloride) in the peritubular space, and especially when the urinary urea concentration is high, the urinary nonurea solute concentration may be an underestimate of the concentration of electrolyte in the medulla. In this regard, it should be noted that when dogs were fed a low protein diet (Table V), a slightly higher nonurea solute concentration was attained during hydropenia than after vasopressin administration during water diuresis. The data of Epstein and his co-workers (17) show a similar relationship in two human subjects fed a low protein diet. An alternative explanation for this apparent effect of the urinary urea concentration is suggested by previous experiments in which the effects of mannitol and urea osmotic diuresis were compared in the dog (20). In that study, at comparable rates of solute excretion, a higher rate of free water absorption was observed during urea diuresis. The urinary nonurea solute concentration was higher, however, during mannitol infusion. The latter observation was attributed to a higher rate of water entry into the medullary interstitium during urea diuresis, with a resultant dilution of the medullary sodium chloride. It should be emphasized, however, that this apparent effect of urea was observed during solute diuresis and consequently may not be directly applicable to the results of the present study.

It has been frequently observed that total urinary osmolality is influenced by the filtered load of urea. The studies by Levinsky and Berliner in the $\operatorname{dog}$ and in man (4) indicate that urea increases urinary osmolality by virtue of its ability to permeate the collecting duct and thus increase the osmolality of the medullary interstitium. According to this theory of action of urea. the sodium chloricle concentration of the medullary interstitium should be essentially independent of the plasma or urinary urea concentration. The present data support this view, and indicate that when filtration rate is not concomitantly reduced, lowering the plasma urea concentration does not reduce the ability of the kidney to concentrate nonpermeating solute in the urine. These observations appear to be at variance with those of $\mathrm{Ma}$ nitius. Pigeon, and Epstein (21), who observed a decrease in nonurea solute concentration of the urine during mannitol diuresis in dogs on a low protein diet. That the infusion of urea did not correct this concentrating defect indicates that it was not a direct result of a decreased filtered load of urea. This apparent discrepancy may be attributable to the degree of protein depletion induced in the present study and that of Manitius and his co-workers. It should be noted that dogs in the present experiments were studied after only 5 days on a low protein diet. They maintained body weight during this period and in all instances but one, failed to show a decrease in GFR below control values. Thus it seems likely that the present study produced insignificant degrees of cellular protein depletion, and that this factor did not complicate examination of the effect of a lowered filtered urea load per se. The studies of Crawford. Doyle, and Probst indicate that the filtered urea load does influence the urinary concentration of nonpermeating solutes in the rat (22). Recent studies suggest, however, that urea may be actively accumulated in the rat medulla (23), indicating a species difference from the dog.

\section{SUM MARY}

The acute renal effects of vasopressin have been investigated by administration of this hormone in maximally effective amounts to conscious dogs undergoing water diuresis. As measured by the concentration of nonpermeating (nonurea) solutes in the urine, a maximal effect of vasopressin is manifested rapidly, usually within 20 minutes of administration of the hormone. The maximal nonurea solute concentration is not further increased by continued infusion of vasopressin or by the imposition of hydropenia in the same animals. This finding suggests that vasopressin does not increase the medullary sodium chloride gradient, and that the latter is not altered by changes in the degree of body hydration ranging from the hydropenic state to the normally hydrated state on which an acute water load has been superimposed.

Reduction of the plasma concentration of urea. and thus of the filtered load. produced by shortterm dietary deprivation of protein, does not re- 
duce the maximal nonurea solute concentration observed during hydropenia or after vasopressin administration during water diuresis.

A direct relationship between the level of glomerular filtration rate and maximal nonurea solute concentration has been found.

The present study serves to emphasize the multiple variables that must be considered in the quantitative assessment of urinary concentrating ability.

\section{ACKNOWLEDGMENT}

The author is grateful to Mrs. Linda Blann for her able technical assistance.

\section{REFERENCES}

1. Smith, H. W. The fate of sodium and water in the renal tubules. Bull. N. Y. Acad. Med. 1959, 35, 293.

2. Wirz, H. The location of antidiuretic action in the mammalian kidney in The Neurohypophysis, $\mathrm{H}$. Heller, Ed. New York, Academic Press, 1957, p. 157.

3. Gottschalk, C. W., and Mylle, M. Micropuncture study of the mammalian urinary concentrating mechanism: evidence for the countercurrent hypothesis. Amer. J. Physiol. 1959, 196, 927.

4. Levinsky, N. G., and Berliner, R. W. The role of urea in the urine concentrating mechanism. J. clin. Invest. 1959, 38, 741 .

5. Jaenike, J. R. The influence of vasopressin on the permeability of the mammalian collecting duct to urea. J. clin. Invest. 1961, 40, 144.

6. Walser, M., Davidson, D. G., and Orloff, J. The renal clearance of alkali-stable inulin. J. clin. Invest. $1955,34,1520$.

7. Conway, E. J. Micro-Diffusion Analysis and Volumetric Error. London, Crosby, Lockwood, 1957.

8. Bowman, R. L., Trantham, H. V., and Caulfield, P. A. An instrument and method for rapid, dependable determination of freezing-point depression. J. Lab. clin. Med. 1954, 43, 310.

9. Lassiter, W. E., Gottschalk, C. W., and Mylle, M. Micropuncture study of net transtubular movement of water and urea in nondiuretic mammalian kidney. Amer. J. Physiol. 1961, 200, 1139.

10. Shannon, J. A. Glomerular filtration and urea excretion in relation to urine flow in the dog. Amer. J. Physiol. 1936, 117, 206.

11. Earley, L. E., Sidel, V. W., and Orloff, J. Factors influencing permeability of a vasopressin-sensitive membrane. Fed. Proc. 1962, 21, 145.

12. Goldsmith, C., Beasley, H. K., Whalley, P. J., Rector, F. C., Jr., and Seldin, D. W. The effect of salt deprivation on the urinary concentrating mechanism in the dog. J. clin. Invest. 1961, 40, 2043.

13. Berliner, R. W., and Davidson, D. G. Production of hypertonic urine in the absence of pituitary antidiuretic hormone. J. clin. Invest. 1957, 36, 1416.

14. Bray, G. A. Freezing point depression of rat kidney slices during water diuresis and antidiuresis. Amer. J. Physiol. 1960, 199, 915.

15. Gottschalk, C. W. Micropuncture studies of tubular function in the mammalian kidney. Physiologist 1961, 4, 35.

16. Levitin, H., Goodman, A., Pigeon, G., and Epstein, F. H. Composition of the renal medulla during water diuresis. J. clin. Invest. 1962, 41, 1145.

17. Epstein, F. H., Kleeman, C. R., and Hendrikx, A. The influence of bodily hydration on the renal concentrating process. J. clin. Invest. 1957, 36, 629.

18. West, C. D., Traeger, J., and Kaplan, S. A. A comparison of the relative effectiveness of hydropenia and of Pitressin ${ }^{\circledR}$ in producing a concentrated urine. J. clin. Invest. 1955, 34, 887.

19. Jones, R. V. H., and de Wardener, H. E. Urine concentration after fluid deprivation or pitressin tannate in oil. Brit. med. J. 1956, 1, 271.

20. Jaenike, J. R. Urea enhancement of water reabsorption in the renal medulla. Amer. J. Physiol. 1960, $199,1205$.

21. Manitius, A., Pigeon, G., and Epstein, F. H. The influence of dietary protein and urea on renal concentrating ability in dogs. Clin. Res. 1962, 10, 252.

22. Crawford, J. D., Doyle, A. P., and Probst, J. H. Service of urea in renal water conservation. Amer. J. Physiol. 1959, 196, 545.

23. Bray, G. A., and Preston, A. S. Effect of urea on urine concentration in the rat. J. clin. Invest. 1961, 40, 1952. 